\title{
Evaluation of 4 different teat disinfection methods prior to collection of milk samples for bacterial culture in dairy cattle
}

\author{
K. Wattenburger, R. Schmidt, L. Placheta, J. R. Middleton, $\odot$ and P. R. F. Adkins* ${ }^{\circ}$ \\ Department of Veterinary Medicine and Surgery, University of Missouri, Columbia 65211
}

\begin{abstract}
The first objective of this study was to determine whether differences would occur among teat end preparation techniques with regard to potential contamination of milk samples collected for bacterial culture. The second objective was to determine whether differences would be detected in genus or species of bacteria isolated from samples collected using the various methods as well as from contaminated or uncontaminated samples. Mammary quarter foremilk samples were collected from lactating dairy cattle at the University of Missouri Foremost Research Dairy Farm (Columbia). Four different teat end preparation methods were used to compare contamination rates in milk samples. Sampling techniques used before milk collection included (1) no preparation, (2) pre-milking disinfection and single-use towel drying of teats only, (3) scrubbing of the teat end with alcohol only, and (4) pre-milking disinfection, single-use towel drying, and scrubbing of the teat end with alcohol. Milk was plated on Columbia blood agar. Cultures were read at $48 \mathrm{~h}$, with the number of morphologically different bacterial colony types quantified and isolated. Isolates were identified using MALDI-TOF mass spectrometry. Median numbers of colony types were compared among groups using Kruskal-Wallis ANOVA with post-hoc pairwise comparisons, and proportional data were compared using the chi-squared test. A total of 168 cows, including 665 quarters, were sampled, and 1,614 isolates resulted. Analysis with MALDI-TOF identified 29 unique genera and 81 unique species among the samples. More contaminated samples occurred in groups 1 and 2 compared with groups 3 and 4 . Group 3 had more contaminated samples than group 4. The majority of Pseudomonas spp. isolates were identified within group 2. When applying previously described niches to Staphylococcus spp., environmental species were more likely to be identified among contaminated
\end{abstract}

Received July 26, 2019.

Accepted December 20, 2019.

*Corresponding author: adkinsp@missouri.edu samples, whereas host-adapted species were more likely to be identified among uncontaminated samples. These data confirm that scrubbing the teat end with alcohol after pre-milking disinfection with an iodine-based teat disinfectant and drying of the teat minimizes contamination of the milk sample.

Key words: milk sample, collection technique, contamination, bacterial identification, MALDI-TOF

\section{INTRODUCTION}

Bacterial culture of milk is one of the primary methods used to diagnose intramammary infections. Aseptic technique is thought to be vital, when collecting milk samples for culture, to minimize false-positive results caused by bacteria on the teat end entering the sample during sample collection. The National Mastitis Council's (NMC) recommended method for aseptically collecting milk includes the following steps: putting on clean gloves, brushing away loose dirt and debris, discarding a few streams of milk, applying a pre-milking teat disinfectant followed by drying the teat with a single-use towel, scrubbing the teat end with gauze soaked in $70 \%$ alcohol, and collecting the milk sample into a sterile vial (Middleton et al., 2017).

Although this approach is recommended, it has never been critically evaluated in a prospective clinical study assessing contamination rates among milk samples collected for conventional bacterial culture and diagnosis of IMI. A few previous studies have evaluated the effect of sampling techniques on real-time PCR diagnosis of an IMI. Specifically, the effect of sampling procedure on real-time PCR diagnosis of a Staphylococcus aureus intramammary infection was studied by Mahmmod et al. (2013). In that study, routine pre-milking teat end preparation practices, which included cleaning of the teat with a towel, but no pre-milking disinfection, was compared with specific pre-sampling procedures, which included teat cleaning, discarding the first milk streams, and $70 \%$ alcohol teat disinfection. Specific pre-sampling procedures decreased the odds of a milk sample being classified as $S$. aureus PCR-positive, compared with samples in which pre-sampling proce- 
dures were not carried out (Mahmmod et al., 2013). Collecting milk samples directly from the udder cistern has also been shown to result in a lower number of different species identified per sample using real-time PCR, compared with conventional sampling techniques through the teat canal (Hiitio et al., 2016). Bypassing the teat skin, teat orifice, and teat canal excluded a large portion of microbes that can be found in bovine milk samples (Hiitiö et al., 2016). These studies provide preliminary evidence on the importance of teat end preparation technique before milk sample collection to maximize diagnostic outcomes and minimize sample contamination.

The teat end can harbor diverse populations of bacteria (Derakhshani et al., 2018). Using cultureindependent techniques, the bacteria found on the teat end have been shown to consist of 4 dominant phyla: Firmicutes, Actinobacteria, Proteobacteria, and Bacteroidetes (Braem et al., 2012). Within these phyla, dominant genera include Aerococcus, Acinetobacter, Corynebacterium, Jeotgalicoccus, Staphylococcus, Psychrobacter, Kocuria, Streptococcus, and Bifidobacterium (Braem et al., 2012). Many of these same genera have also been identified as normal teat end microbiota using culture-dependent methods, with the most common genera identified using conventional culture being $\mathrm{Co}$ rynebacterium, Staphylococcus, Bacillus, and Acinetobacter (Woodward et al., 1987).

Among species frequently identified on the teat end, staphylococcal species are also very commonly isolated from milk samples, being the most prevalent group of bacteria found in bovine milk samples in many areas of the world (Pitkälä et al., 2004; Tenhagen et al., 2006; Rowbotham and Ruegg, 2016). Common species identified in milk include Staphylococcus chromogenes, Staphylococcus simulans, and Staphylococcus xylosus (Fry et al., 2014; Condas et al., 2017), and Staphylococcus devriesei, S. chromogenes, and Staphylococcus haemolyticus are among the most frequently isolated species from teat skin samples (De Visscher et al., 2016; Adkins et al., 2018). The primary reservoir for each staphylococcal species is variable. The udder is thought to be the primary reservoir for some species, such as S. aureus (Rainard et al., 2018), S. chromogenes, and Staphylococcus epidermidis (Piessens et al., 2011), whereas the environment is thought to be the primary reservoir for others, such as Staphylococcus equorum, Staphylococcus sciuri, S. xylosus, and Staphylococcus arlettae (Piessens et al., 2011).

The objective of this study was twofold: (1) to determine whether differences among teat end preparation techniques occur with regard to potential contamination of milk samples for culture, and (2) to determine any difference in the genus or species of bacteria found among sampling methods and between contaminated and uncontaminated samples.

\section{MATERIALS AND METHODS}

\section{Herd and Cow Selection}

The study was approved by the University of Missouri Animal Care and Use Committee (protocol number 9391). Cows for the study were housed at the University of Missouri Foremost Research Dairy Farm (Columbia). All cattle housed in pens bedded with shavings on top of mattresses were sampled for the study. Intramammary infection status at the time of study enrollment was unknown. Cows were milked twice daily in a double- 8 herringbone parlor. Routine milking procedures included spraying teat ends with a $0.5 \%$ iodine teat disinfectant followed by hand stripping. Teats were then dried with individual towels that were washed, but not dried, on-site between each use. A post-milking $1.0 \%$ iodine disinfectant was applied using a dip cup at the end of milking. All milkers wore disposable nitrile gloves during milking.

\section{Sample Collection}

Mammary quarter foremilk samples were collected just before routine milking. For the purposes of this study, routine pre-milking procedures (noted above) were modified to allow evaluation of the study objectives. Four different teat end preparation methods were randomly assigned, 1 to each teat within a cow, such that each cow received all 4 treatments. Cows were numbered based on order of entry into the parlor, and treatments were randomized using a random number generator. Treatment groups were as follows: (1) no preparation of the teat end before milk sample collection, (2) teat sprayed with an iodine-based pre-milking teat disinfectant and dried with a single-use towel before milk sample collection, (3) teat end scrubbed with $70 \%$ isopropyl alcohol before milk sample collection, and (4) teat sprayed with an iodine-based pre-milking teat disinfectant, dried with a single-use towel, and finally scrubbed with a $70 \%$ isopropyl alcohol-soaked cotton pad before milk sample collection. Each teat was individually prepared based on selected treatment group just before sample collection. The germicidal teat disinfectant (ES 5000, Dairy Star, Naperville, IL) used in groups 2 and 4 was the same iodine-based commercially available product. The single-use towels were washed on-site at the University of Missouri Foremost Research Dairy Farm but not dried (Fox, 1997). In all cases, the person collecting the samples wore clean disposable latex gloves. 
Milk samples were taken during 2 morning milking shifts in the summer of 2018. Milk samples were collected into sterile 5-mL polystyrene tubes (Falcon, Tewksbury, MA). After collection, samples were chilled on ice, transported to the laboratory, and frozen at $-20^{\circ} \mathrm{C}$ until further processing.

\section{Laboratory Procedures}

Milk samples were thawed at room temperature $\left(\sim 22^{\circ} \mathrm{C}\right)$. Approximately $10 \mu \mathrm{L}$ of milk was plated on Columbia blood agar (CBA; Remel, Lenexa, KS) using a sterile cotton-tipped applicator. Plates were incubated at $37^{\circ} \mathrm{C}$ for $24 \mathrm{~h}$ and then at room temperature for 24 h (Roberson et al., 1994). Plates were read at $48 \mathrm{~h}$, and numbers of morphologically different bacterial colony types were recorded. The person reading the culture plates was blinded to the treatment group from which the sample was collected. All morphologically different bacterial colony types were subcultured onto CBA for further identification.

Isolates were identified to the genus and, when possible, species level, using matrix-assisted laser desorption/ionization time-of-flight (MALDI-TOF) mass spectrometry. Samples were processed on a MALDITOF mass spectrometer (Microflex, Bruker Daltonics, Bremen, Germany) using Flex Control software (Bruker Daltonics). The MALDI-TOF target plate was prepared using the plate extraction method (Brucker Daltonics), as previously described (Adkins et al., 2018). Briefly, 1 colony of each bacterial isolate was spotted on the MALDI-TOF target plate in duplicate. The sample was then overlaid with $1 \mu \mathrm{L}$ of $70 \%$ formic acid, which was allowed to dry. The spot was then overlaid with $1 \mu \mathrm{L}$ of matrix solution (Bruker Daltonics). Peaks produced by each sample were compared with entries in the manufacturer's database and the University of Missouri laboratory custom database (Adkins et al., 2018) using the standard parameters of the pattern-matching algorithm. Species identification cutoff values were applied according to the manufacturer's instructions, in which a score of $\geq 2$ indicated a species-level identification and a score of between $\geq 1.7$ and $<2$ indicated a genus-level identification. An alternative cutoff value was used for Staphylococcus spp. (Cameron et al., 2017), in which $\geq 1.7$ was used for species-level identification. For all bacteria types, any score $<1.7$ was classified as inconclusive.

\section{Definitions}

An uncontaminated sample was a sample with 1 or 2 colony types identified. A contaminated sample was a sample with $\geq 3$ colonies types identified (Middleton et al., 2017). An isolate identified as No ID was one in which MALDI-TOF identification was inconclusive. Staphylococcal species were grouped into host-adapted ( $S$. aureus, S. chromogenes, and S. epidermidis), opportunistic ( $S$. haemolyticus and $S$. simulans), or environmental (S. equorum, S. sciuri, and S. xylosus) based on previously described categorizations (Piessens et al., 2011; Rainard et al., 2018). All other identified staphylococcal species (Staphylococcus hominis, Staphylococcus auricularis, Staphylococcus saprophyticus, S. arlettae, Staphylococcus gallinarum, and Staphylococcus agnetis or Staphylococcus hyicus) were grouped as unclassified. Because MALDI-TOF is unable to differentiate S. agnetis from S. hyicus (Adkins et al., 2018), isolates classified as either were grouped as S. agnetis/hyicus.

\section{Statistical Analyses}

Species and genus prevalence were expressed as absolute numbers and percentages. Data were analyzed using a Kruskal-Wallis one-way ANOVA on ranks to compare the median number of colony types isolated from milk samples among the groups, with post-hoc pairwise comparisons made using Dunn's method. Data were also stratified based on number of samples in each group with $\geq 3$ colony types (i.e., contaminated versus uncontaminated) and compared using a chi-squared test. Data were analyzed using commercial software (SigmaPlot 14.0, Systat Software, San Rafael, CA), and significance was declared at $P<0.05$.

\section{RESULTS}

A total of 168 cows were sampled, including 665 quarters (7 quarters yielded no milk sample). Treatment groups 1, 2, 3, and 4 included 167, 167, 168, and 163 quarters, respectively. No bacterial growth occurred in $12.6 \%$ (21 out of 167), $11.3 \%$ (19 of 167), $40.5 \%$ (68 of 168 ), and $49.1 \%$ (80 of 163) of samples for groups 1, 2, 3 , and 4 , respectively. Only 1 colony type was isolated from $10.8 \%$ (18 of 167), $13.2 \%$ (22 of 167 ), $30.4 \%$ (51 of 168 ), and $28.8 \%$ (47 of 163) of samples for groups 1 , 2,3 , and 4 , respectively. A total of 2 colony types were isolated from $14.4 \%$ (24 of 167), $12.0 \%$ (20 of 167), $10.1 \%$ (17 of 168), and $11.7 \%$ (19 of 163) of samples for groups $1,2,3$, and 4 , respectively. The contamination rates were $62 \%$ (104 of 167), $63 \%$ (106 of 167), 19\% (32 of 168), and $10 \%$ (17 of 163) for groups 1, 2, 3, and 4, respectively $(P<0.01)$. Only 1 quarter, within group 2 , was noted to have clinical mastitis. That quarter had a single colony type isolated from the milk, which was identified as Streptococcus dysgalactiae.

A total of 1,614 bacterial colony types were enumerated and isolated. Up to 12 unique colony types were 
Table 1. Number (percent) of each genus identified within each treatment group; percentages represent the number of the given genus identified within the given treatment group out of the total number within the given treatment group

\begin{tabular}{|c|c|c|c|c|c|}
\hline \multirow[b]{2}{*}{ Genus } & \multicolumn{4}{|c|}{$\begin{array}{c}\text { Treatment group }{ }^{1} \\
\text { no. }(\%)\end{array}$} & \multirow[b]{2}{*}{ Total } \\
\hline & 1 & 2 & 3 & 4 & \\
\hline Corynebacterium & $180(28.0)$ & $137(24.5)$ & $49(21.3)$ & $38(24.7)$ & 404 \\
\hline No ID & $175(27.2)$ & $133(23.8)$ & $55(23.9)$ & $40(26.0)$ & 403 \\
\hline Staphylococcus & $117(18.2)$ & $104(18.6)$ & $55(23.9)$ & $32(20.8)$ & 308 \\
\hline Aerococcus & $87(13.5)$ & $95(17.0)$ & $17(7.4)$ & $12(7.8)$ & 211 \\
\hline Bacillus & $41(6.4)$ & $36(6.4)$ & $22(9.6)$ & $21(13.6)$ & 120 \\
\hline Pseudomonas & $0(0)$ & $21(3.8)$ & $0(0)$ & $1(0.6)$ & 22 \\
\hline Micrococcus & $3(0.5)$ & $4(0.7)$ & $7(3.0)$ & $3(1.9)$ & 17 \\
\hline Acinetobacter & $10(1.6)$ & $2(0.4)$ & $1(0.4)$ & $1(0.6)$ & 14 \\
\hline Paenibacillus & $4(0.6)$ & $5(0.9)$ & $3(1.3)$ & $0(0)$ & 12 \\
\hline Escherichia & $6(0.9)$ & $2(0.4)$ & $3(1.3)$ & $0(0)$ & 11 \\
\hline Brevibacterium & $3(0.5)$ & $4(0.7)$ & $2(0.9)$ & $1(0.6)$ & 10 \\
\hline Streptococcus & $0(0)$ & $2(0.4)$ & $6(2.6)$ & $0(0)$ & 8 \\
\hline Globicatella & $4(0.6)$ & $1(0.2)$ & $2(0.9)$ & $0(0)$ & 7 \\
\hline Brevibacillus & $1(0.2)$ & $1(0.2)$ & $2(0.9)$ & $2(1.3)$ & 6 \\
\hline Pseudarthrobacter & $2(0.3)$ & $2(0.4)$ & $0(0)$ & $1(0.6)$ & 5 \\
\hline Enterococcus & $1(0.2)$ & $3(0.5)$ & $0(0)$ & $0(0)$ & 4 \\
\hline Rothia & $0(0)$ & $1(0.2)$ & $2(0.9)$ & $1(0.6)$ & 4 \\
\hline Arthrobacter & $1(0.2)$ & $2(0.4)$ & $0(0)$ & $0(0)$ & 3 \\
\hline Neisseria & $0(0)$ & $1(0.2)$ & $1(0.4)$ & $1(0.6)$ & 3 \\
\hline Alishewanella & $2(0.3)$ & $0(0)$ & $0(0)$ & $0(0)$ & 2 \\
\hline Enterobacter & $1(0.2)$ & $1(0.2)$ & $0(0)$ & $0(0)$ & 2 \\
\hline Lysinibacillus & $2(0.3)$ & $0(0)$ & $0(0)$ & $0(0)$ & 2 \\
\hline Macrococcus & $0(0)$ & $2(0.4)$ & $0(0)$ & $0(0)$ & 2 \\
\hline Candida & $0(0)$ & $0(0)$ & $1(0.4)$ & $0(0)$ & 1 \\
\hline Cellulosimicrobium & $0(0)$ & $1(0.2)$ & $0(0)$ & $0(0)$ & 1 \\
\hline Lactobacillus & $1(0.2)$ & $0(0)$ & $0(0)$ & $0(0)$ & 1 \\
\hline Nocardiopsis & $0(0)$ & $0(0)$ & $1(0.4)$ & $0(0)$ & 1 \\
\hline Sphingobacterium & $1(0.2)$ & $0(0)$ & $0(0)$ & $0(0)$ & 1 \\
\hline Trueperella & $0(0)$ & $0(0)$ & $1(0.4)$ & $0(0)$ & 1 \\
\hline Zimmermannella & $1(0.2)$ & $0(0)$ & $0(0)$ & $0(0)$ & 1 \\
\hline Total & 643 & 560 & 230 & 154 & 1,587 \\
\hline
\end{tabular}

${ }^{1}$ Teats in treatment group 1 had no preparation before collecting the milk sample. Teats in treatment group 2 were sprayed with a pre-milking disinfectant and dried with a single-use towel before collecting the milk sample. Teats in treatment group 3 only had the teat end scrubbed with a cotton swab soaked in $70 \%$ isopropyl alcohol before collecting the milk sample. Teats in treatment group 4 were sprayed with a pre-milking teat disinfectant, dried with a single-use towel, and then scrubbed with a cotton swab soaked in $70 \%$ isopropyl alcohol before collecting the milk sample.

identified per sample. Using MALDI-TOF we were able to identify 1,587 isolates ( 27 isolates were lost in processing). Within the 1,587 isolates, 1,184 (75\%) were identified to the genus level, and 862 (54\%) were identified to the species level.

A total of 29 unique genera and 81 unique species were identified among the samples. Overall, the most common genera identified were Corynebacterium (404 of 1,587, 25.5\%), Staphylococcus (308 of 1,587, 19.4\%), Aerococcus (211 of 1,587, 13.3\%), and Bacillus (120 of 1,587, 7.6\%; Table 1). Within the genus Corynebacterium, 9 different species were identified (Table 2). The most common Corynebacterium included Corynebacterium xerosis (149 of 404, 37\%), Corynebacterium amycolatum (57 of 404, 14\%), and Corynebacterium lipophiloflavum (32 of 404, 7.9\%). No Corynebacterium bovis were identified. All Aerococcus that were identified to the species level were identified as Aerococcus viridans (159 of 211, 75\%). Four different Bacillus species were identified, with the most common being Bacillus licheniformis (42 of 120, 35\%). Within the staphylococcal species, 14 different species were identified, with the most common species being S. equorum (94 of 308, $31 \%)$, S. chromogenes (54 of $308,18 \%$ ), S. arlettae (34 of $308,11 \%$ ), S. hominis (24 of 308, 8\%), and S. aureus (21 of $308,7 \%$; Table 2 ).

The most prevalent bacterial genera were identified within all treatment groups (Table 1). Pseudomonas were identified only in treatment groups that used the spray teat disinfectant (groups 2 and 4), with the majority of Pseudomonas isolates identified in treatment group 2 (21 of 22, 95\%) - pre-milking disinfectant spray without alcohol scrubbing before sample collection. Several bacterial genera were absent from treat- 
ment group 4, including Paenibacillus, Escherichia, and Globicatella. Within the staphylococcal species, the most prevalent species were found among all treatment groups.

Pairwise comparisons showed more contaminated samples in groups 1 and 2 compared with groups 3 and $4(P<0.01)$. Additionally, group 3 had more contaminated samples than did group $4(P=0.04)$. Overall, among the uncontaminated samples, 13 different bacterial genera were identified in samples where only 1 colony type was isolated, 13 different bacterial genera were identified in samples where 2 colony types were isolated, and a total of 17 different bacterial genera were isolated among all uncontaminated samples. Among contaminated samples, 27 different bacterial genera were identified (Table 3 ). Several genera were identified only within contaminated samples; these included Acinetobacter, Brevibacterium, Arthrobacter, Neisseria, Macrococcus, Lysinibacillus, Enterobacter, Alishewanella, Zimmermannella, Sphingobacterium, Lactobacillus, and Cellulosimicrobium (Table 3).

Within the contaminated samples, several staphylococcal species were commonly found (Table 4). Overall, the majority of $S$. equorum (77 of $94,82 \%$ ), S. arlettae (29 of 35, 83\%), S. hominis (20 of 24, 83\%), S. auricularis (17 of 20,85\%), S. haemolyticus (13 of 16, $81 \%)$, S. xylosus (12 of $12,100 \%)$, S. saprophyticus (10 of 10,100\%), S. sciuri (9 of 9,100\%), S. gallinarum (3 of $4,75 \%$ ), and S. agnetis/hyicus (3 of 3, 100\%) were isolated from contaminated samples. When assessing staphylococcal species by putative niches, the host-adapted staphylococci were more prevalent among samples classified as uncontaminated (45 of $80,56 \%$ ) compared with those classified as contaminated (35 of

Table 2. Percentage of Staphylococcus, Corynebacterium, and Bacillus species identified within each treatment group; percentages represent the number of the given species identified within the given treatment group out of the total number of the given species identified

\begin{tabular}{|c|c|c|c|c|c|}
\hline \multirow[b]{2}{*}{ Species } & \multicolumn{4}{|c|}{$\begin{array}{c}\text { Treatment group }^{1} \\
\text { no. }(\%)\end{array}$} & \multirow[b]{2}{*}{ Total } \\
\hline & 1 & 2 & 3 & 4 & \\
\hline Staphylococcus equorum & $42(45)$ & $37(39)$ & $11(12)$ & $4(4)$ & 94 \\
\hline Staphylococcus chromogenes & $13(24)$ & $14(26)$ & $19(35)$ & $8(15)$ & 54 \\
\hline Staphylococcus arlettae & $14(40)$ & $14(40)$ & $4(11)$ & $3(9)$ & 35 \\
\hline Staphylococcus hominis & $8(33)$ & $8(33)$ & $6(25)$ & $2(8)$ & 24 \\
\hline Staphylococcus aureus & $5(24)$ & $4(19)$ & $5(24)$ & $7(33)$ & 21 \\
\hline Staphylococcus auricularis & $10(50)$ & $4(20)$ & $5(25)$ & $1(5)$ & 20 \\
\hline Staphylococcus haemolyticus & $5(31)$ & $7(44)$ & $2(13)$ & $2(13)$ & 16 \\
\hline Staphylococcus xylosus & $5(42)$ & $5(42)$ & $0(0)$ & $2(17)$ & 12 \\
\hline Staphylococcus saprophyticus & $3(30)$ & $6(60)$ & $1(10)$ & $0(0)$ & 10 \\
\hline Staphylococcus sciuri & $4(44)$ & $4(44)$ & $1(11)$ & $0(0)$ & 9 \\
\hline Staphylococcus epidermidis & $2(40)$ & $0(0)$ & $1(20)$ & $2(40)$ & 5 \\
\hline Staphylococcus gallinarum & $3(75)$ & $0(0)$ & $0(0)$ & $1(25)$ & 4 \\
\hline Staphylococcus agnetis/hyicus & $2(67)$ & $1(33)$ & $0(0)$ & $0(0)$ & 3 \\
\hline Staphylococcus simulans & $1(100)$ & $0(0)$ & $0(0)$ & $0(0)$ & 1 \\
\hline Corynebacterium xerosis & $74(50)$ & $50(34)$ & $19(13)$ & $6(4)$ & 149 \\
\hline Corynebacterium spp. ${ }^{2}$ & $58(43)$ & $52(38)$ & $12(9)$ & $14(10)$ & 136 \\
\hline Corynebacterium amycolatum & $22(39)$ & $18(32)$ & $9(16)$ & $8(14)$ & 57 \\
\hline Corynebacterium lipophiloflavum & $11(34)$ & $5(16)$ & $7(22)$ & $9(28)$ & 32 \\
\hline Corynebacterium variabile & $5(50)$ & $4(40)$ & $1(10)$ & $0(0)$ & 10 \\
\hline Corynebacterium casei & $6(60)$ & $3(30)$ & $0(0)$ & $1(10)$ & 10 \\
\hline Corynebacterium ammoniagenes & $1(25)$ & $2(50)$ & $1(25)$ & $0(0)$ & 4 \\
\hline Corynebacterium freneyi & $2(50)$ & $2(50)$ & $0(0)$ & $0(0)$ & 4 \\
\hline Corynebacterium glutamicum & $0(0)$ & $1(100)$ & $0(0)$ & $0(0)$ & 1 \\
\hline Corynebacterium stationis & $1(100)$ & $0(0)$ & $0(0)$ & $0(0)$ & 1 \\
\hline Bacillus spp. $^{2}$ & $21(32)$ & $20(30)$ & $12(18)$ & $13(20)$ & 66 \\
\hline Bacillus licheniformis & $16(38)$ & $12(29)$ & $8(19)$ & $6(14)$ & 42 \\
\hline Bacillus pumilus & $4(44)$ & $3(33)$ & $2(22)$ & $0(0)$ & 9 \\
\hline Bacillus clausii & $0(0)$ & $0(0)$ & $0(0)$ & $2(100)$ & 2 \\
\hline Bacillus subtilis & $0(0)$ & $1(100)$ & $0(0)$ & $0(0)$ & 1 \\
\hline
\end{tabular}

${ }^{1}$ Teats in treatment group 1 had no preparation before collecting the milk sample. Teats in treatment group 2 were sprayed with a pre-milking disinfectant and dried with a single-use towel before collecting the milk sample. Teats in treatment group 3 only had the teat end scrubbed with a cotton swab soaked in $70 \%$ isopropyl alcohol before collecting the milk sample. Teats in treatment group 4 were sprayed with a pre-milking teat disinfectant, dried with a single-use towel, and then scrubbed with a cotton swab soaked in $70 \%$ isopropyl alcohol before collecting the milk sample.

${ }^{2}$ Isolates identified as Corynebacterium spp. or Bacillus spp. had a MALDI-TOF identification score of $>1.7$ but $<2.0$ and therefore could be characterized only to the genus level. 
$228,15 \% ; P<0.01)$. In contrast, staphylococci classified as environmental were more prevalent among staphylococci isolated from contaminated (98 of 228 , $43 \%$ ) than uncontaminated samples (17 of $80,21 \%$; $P<0.01)$. Similarly unclassified staphylococci were more prevalent among the contaminated (82 of 228 , $36 \%$ ) than uncontaminated samples (14 of $80,18 \%$; $P$ $<0.01)$. When assessing opportunistic staphylococci, no detectable difference in prevalence occurred between the contaminated (13 of $228,6 \%)$ and uncontaminated samples (4 of $80,5 \% ; P=0.962)$.

\section{DISCUSSION}

Overall, the NMC recommended method of sample collection was the most successful at obtaining uncontaminated samples. Although this method is generally used in studies evaluating bovine intramammary infections (Bradley et al., 2015; Godden et al., 2016), some authors report skipping the pre-milking teat disinfectant application and drying step and only preparing teats by

Table 3. Number (percent) of each genus identified within uncontaminated and contaminated samples ${ }^{1}$; percentage is the number of the given genus identified within the given group (uncontaminated or contaminated) out of the total number of the given genus identified

\begin{tabular}{|c|c|c|c|}
\hline Genus & $\begin{array}{c}\text { Uncontaminated } \\
\text { no. }(\%)\end{array}$ & $\begin{array}{c}\text { Contaminated } \\
\text { no. }(\%)\end{array}$ & Total \\
\hline Corynebacterium & $75(19)$ & $329(81)$ & 404 \\
\hline No ID & $67(17)$ & $336(83)$ & 403 \\
\hline Staphylococcus & $80(26)$ & $228(74)$ & 308 \\
\hline Aerococcus & $24(11)$ & $187(89)$ & 211 \\
\hline Bacillus & $14(12)$ & $106(88)$ & 120 \\
\hline Pseudomonas & $6(27)$ & $16(73)$ & 22 \\
\hline Micrococcus & $4(24)$ & $13(76)$ & 17 \\
\hline Acinetobacter & $0(0)$ & $14(100)$ & 14 \\
\hline Paenibacillus & $3(25)$ & $9(75)$ & 12 \\
\hline Escherichia & $2(18)$ & $9(82)$ & 11 \\
\hline Brevibacterium & $0(0)$ & $10(100)$ & 10 \\
\hline Streptococcus & $4(50)$ & $4(50)$ & 8 \\
\hline Globicatella & $1(14)$ & $6(86)$ & 7 \\
\hline Brevibacillus & $2(33)$ & $4(67)$ & 6 \\
\hline Pseudarthrobacter & $1(20)$ & $4(80)$ & 5 \\
\hline Rothia & $1(25)$ & $3(75)$ & 4 \\
\hline Enterococcus & $0(0)$ & $4(100)$ & 4 \\
\hline Arthrobacter & $0(0)$ & $3(100)$ & 3 \\
\hline Neisseria & $0(0)$ & $3(100)$ & 3 \\
\hline Alishewanella & $0(0)$ & $2(100)$ & 2 \\
\hline Enterobacter & $0(0)$ & $2(100)$ & 2 \\
\hline Lysinibacillus & $0(0)$ & $2(100)$ & 2 \\
\hline Macrococcus & $0(0)$ & $2(100)$ & 2 \\
\hline Candida & $1(100)$ & $0(0)$ & 1 \\
\hline Nocardiopsis & $1(100)$ & $0(0)$ & 1 \\
\hline Trueperella & $1(100)$ & $0(0)$ & 1 \\
\hline Cellulosimicrobium & $0(0)$ & $1(100)$ & 1 \\
\hline Lactobacillus & $0(0)$ & $1(100)$ & 1 \\
\hline Sphingobacterium & $0(0)$ & $1(100)$ & 1 \\
\hline Zimmermannella & $0(0)$ & $1(100)$ & 1 \\
\hline
\end{tabular}

${ }^{1}$ An uncontaminated sample was one in which $<3$ colony types were identified on primary culture. A contaminated sample was one in which $\geq 3$ colony types were identified on primary culture. scrubbing with alcohol (Mahmmod et al., 2013). The combination of pre-milking disinfection, drying teats, and cleaning the teat ends with alcohol resulted in the fewest contaminated samples in the present study, and is therefore recommended.

Interestingly, some organisms in this study appeared to be associated with the pre-milking disinfectant, specifically Pseudomonas species. Pseudomonas aeruginosa mastitis has previously been found to be associated with contaminated teat wipes (Sol et al., 1998; Daly et al., 1999), water in the milking parlor wash hoses (Kirk and Bartlett, 1984), the plumbing system (Kirk and Bartlett, 1984; Erskine et al., 1987), and udder wash water with iodine added at levels below the recommended concentration (Erskine et al., 1987). This finding highlights concerns regarding water and potentially inappropriate iodine concentrations with regard to Pseudomonas exposure. The $0.5 \%$ iodine spray premilking disinfectant used by the farm did not require mixing. For the purpose of this study, the disinfectant was not cultured, and therefore it is unknown whether the Pseudomonas was coming from the teat dip, the gland, or an environmental source.

Many of the organisms found in the contaminated milk samples were similar to those that have been identified on the teat ends of dairy cattle in other studies, highlighting the fact that the teat end is a source of contamination. Genera that were prevalent in this study, including Corynebacterium, Staphylococcus, Aerococcus, and Acinetobacter, have been identified on the teat end using culture-independent (Braem et al., 2012) and culture-dependent methods (Woodward et al., 1987). This study is the first to evaluate milk sample contamination associated with teat end hygiene methods using conventional milk microbiology and MALDI-TOF. Using these methods, many different genus and species were identified, demonstrating the wide diversity of bacteria that can be found in milk samples, especially if aseptic sample collection methods are not followed. Additionally, using bacterial culture demonstrated that bacterial species identified on teat ends in other studies using culture-independent techniques can be found alive in contaminated milk samples.

We did not collect SCC data in this study, and therefore it is not possible to determine the prevalence of subclinical mastitis and the influence of any isolated organisms on udder health among sampled quarters. Subclinical mastitis is most often due to bacterial IMI. Because gold standard tests do not exist, definitions for both subclinical mastitis and IMI are debatable (Dohoo et al., 2011) In general, culturing techniques have limited sensitivity, and the problem intensifies when anything more than $100 \mathrm{cfu} / \mathrm{mL}$ is required to define an IMI (Dohoo et al., 2011). That said, sampling 
through the teat end, even with appropriate aseptic technique, does not ensure that the bacteria in the milk is from the gland, as the sample must pass through the teat canal, which is continuous with the teat skin. Both the canal and the skin can be colonized, making contamination an inevitable component of the sampling technique (Hiitiö et al., 2016). In this study, microbiota present in the milk may consist of microbes coming from the gland or from extramammary sites, or both.

The categorization of staphylococcal species according to niche on the dairy farm, as previously defined (Piessens et al., 2011; Rainard et al., 2018), seemed to hold true in this study. Overall, environmental staphylococcal species were more likely to be found in contaminated samples, whereas host-adapted species were more likely to be found in uncontaminated samples. Also, as might be expected, opportunistic species were identified with similar prevalences among both uncontaminated and contaminated samples. Several species, such as $S$. chromogenes, S. epidermidis, and $S$. simulans, are associated with elevations in SCC and have been found to be associated with persistent IMI and therefore influence udder health (Fry et al., 2014). Additionally, species known to cause IMI, such as $S$. chromogenes, S. haemolyticus, and S.xylosus can also commonly reside on the teat end, and heifers that have S. chromogenes, S. simulans, or S. xylosus identified on their teat skin prior to calving show increased odds of having a post-calving IMI with the same NAS species (Adkins et al., 2018). However, previous work that bypassed the teat identified half the number of samples positive for Staphylococcus spp., compared with conventional milk sampling techniques (Hiitiö et al., 2016), showing that not all staphylococcal species are likely causing a true IMI. Unfortunately, in that study, speciation of staphylococcal isolates was not conducted. Therefore, further work is needed to determine which staphylococcal species are truly associated with IMI and which ones tend to inhabit the teat end or canal.

Interspecies relationships among bacteria identified within a single sample were not part of the objectives of this study and therefore were not evaluated. Previous work has found that some teat-associated bacteria, specifically NAS species, can display antibacterial activities

Table 4. Number (percent) of Staphylococcus, Corynebacterium, and Bacillus species identified within mammary quarter milk samples in which 1 colony type, 2 colony types, or $\geq 3$ colony types were isolated; percentage is the number of the given species identified within the given group ( 1 colony, 2 colonies, $\geq 3$ colonies) out of the total number of the given species identified

\begin{tabular}{|c|c|c|c|c|}
\hline Species & $\begin{array}{l}1 \text { Colony } \\
\text { no. }(\%)\end{array}$ & $\begin{array}{c}2 \text { Colonies } \\
\text { no. }(\%)\end{array}$ & $\begin{array}{c}\geq 3 \text { Colonies } \\
\text { no. }(\%)\end{array}$ & Total \\
\hline Staphylococcus equorum & $3(3.2)$ & $14(15)$ & $77(82)$ & 94 \\
\hline Staphylococcus chromogenes & $20(37)$ & $9(17)$ & $25(46)$ & 54 \\
\hline Staphylococcus arlettae & $2(6)$ & $4(11)$ & $29(83)$ & 35 \\
\hline Staphylococcus hominis & $1(4)$ & $3(13)$ & $20(83)$ & 24 \\
\hline Staphylococcus aureus & $7(33)$ & $5(24)$ & $9(43)$ & 21 \\
\hline Staphylococcus auricularis & $1(5)$ & $2(10)$ & $17(85)$ & 20 \\
\hline Staphylococcus haemolyticus & $2(13)$ & $1(6)$ & $13(81)$ & 16 \\
\hline Staphylococcus xylosus & $0(0)$ & $0(0)$ & $12(100)$ & 12 \\
\hline Staphylococcus saprophyticus & $0(0)$ & $0(0)$ & $10(100)$ & 10 \\
\hline Staphylococcus sciuri & $0(0)$ & $0(0)$ & $9(100)$ & 9 \\
\hline Staphylococcus epidermidis & $4(80)$ & $0(0)$ & $1(20)$ & 5 \\
\hline Staphylococcus gallinarum & $1(25)$ & $0(0)$ & $3(75)$ & 4 \\
\hline Staphylococcus agnetis/hyicus & $0(0)$ & $0(0)$ & $3(100)$ & 3 \\
\hline Staphylococcus simulans & $1(100)$ & $0(0)$ & $0(0)$ & 1 \\
\hline Corynebacterium xerosis & $8(5)$ & $12(8)$ & $129(87)$ & 149 \\
\hline Corynebacterium spp. ${ }^{1}$ & $13(10)$ & $14(10)$ & $109(80)$ & 136 \\
\hline Corynebacterium amycolatum & $7(12)$ & $7(12)$ & $43(75)$ & 57 \\
\hline Corynebacterium lipophiloflavum & $6(19)$ & $6(19)$ & $20(63)$ & 32 \\
\hline Corynebacterium variabile & $1(10)$ & $0(0)$ & $9(90)$ & 10 \\
\hline Corynebacterium casei & $0(0)$ & $0(0)$ & $10(100)$ & 10 \\
\hline Corynebacterium ammoniagenes & $0(0)$ & $0(0)$ & $4(100)$ & 4 \\
\hline Corynebacterium freneyi & $0(0)$ & $0(0)$ & $4(100)$ & 4 \\
\hline Corynebacterium glutamicum & $0(0)$ & $0(0)$ & $1(100)$ & 1 \\
\hline Corynebacterium stationis & $1(100)$ & $0(0)$ & $0(0)$ & 1 \\
\hline Bacillus spp. ${ }^{1}$ & $7(11)$ & $3(5)$ & $56(85)$ & 66 \\
\hline Bacillus licheniformis & $1(2)$ & $3(7)$ & $38(91)$ & 42 \\
\hline Bacillus pumilus & $0(0)$ & $0(0)$ & $9(100)$ & 9 \\
\hline Bacillus clausii & $0(0)$ & $0(0)$ & $2(100)$ & 2 \\
\hline Bacillus subtilis & $0(0)$ & $0(0)$ & $1(100)$ & 1 \\
\hline
\end{tabular}

${ }^{1}$ Isolates identified as Corynebacterium spp. or Bacillus spp. had a MALDI-TOF identification score of $>1.7$ but $<2.0$ and therefore could be characterized only to the genus level. 
in vitro (De Vliegher et al., 2004; Braem et al., 2014). In one study, antibacterial activity was identified in at least $13 \%$ of coagulase-negative staphylococcal species originating from the teat ends of dairy cows (Braem et al., 2014) Previous work has evaluated antibacterial activity against known mastitis pathogens; however, future studies are needed to determine how bacteriocinproducing species influence teat end microbiota.

In a previous report, $93.5 \%$ of bacteria isolated from cases of bovine mastitis were identified to the species level using MALDI-TOF with a diagnostic score of $\geq 2$ (Nonnemann et al., 2019). In our study, only $54 \%$ of isolates were identified to the species level, and $25 \%$ of isolates could not be identified to the genus level using MALDI-TOF even at the lower diagnostic threshold of $\geq 1.7$. This discrepancy in findings is likely related to the sample type. In this study, contaminants were also evaluated, and therefore many environmental organisms were included. Overall, the MALDI-TOF databases are considered incomplete with regard to environmental isolates (Popović et al., 2017). Additionally, in this study, ethanol-formic acid-acetonitrile extractions were not performed, which have been shown to result in greater numbers of high-level identifications compared with direct colony testing (Alatoom et al., 2011).

One limitation of this study was that milk samples were cultured only after freezing. Freezing milk samples for up to 16 weeks does not affect the viability of grampositive cocci (Schukken et al., 1989) and can increase the likelihood of detection of staphylococcal (Schukken et al., 1989; Godden et al., 2002) and streptococcal species (Villanueva et al., 1991). However, freezing can adversely affect the recovery of some bacterial genera and species, such as Escherichia coli and Trueperella pyogenes (Schukken et al., 1989). With regard to this study, it is possible that some bacterial genera and species were not recovered or were recovered less frequently due to the effect of freezing. Additionally, however, freezing of milk samples is commonplace in many studies on IMI. Milk sample contamination or false-positive results can occur easily on farm, with contamination rates ranging from 2.3 to $6.6 \%$ in other studies (Gohary and McDougall, 2018; Naqvi et al., 2018). In the present study, the contamination rate in group 4 , the group that followed NMC teat preparation guidelines, was slightly higher than in previous reports, with a contamination rate of $10 \%$. This finding is likely related to the fact that many different treatment protocols were being applied within cow, potentially leading to some error. However, even with a slightly higher contamination rate than expected, our data demonstrate that the NMC recommended method is the best approach for minimizing sample contamination and thus falsepositive milk culture results.

\section{CONCLUSIONS}

Overall, these data confirm that scrubbing the teat end with alcohol after pre-milking disinfection with an iodine-based teat disinfectant and drying with a singleuse towel minimizes contamination of milk samples. Additionally, certain genera of bacteria were more likely to be identified when using minimal preparation methods. When applying previously described niches to the Staphylococcus spp., environmental species were more likely to be identified among contaminated samples, whereas host-adapted species were more likely to be identified among uncontaminated samples.

\section{ACKNOWLEDGMENTS}

This project was funded in part by the University of Missouri College of Veterinary Medicine (Columbia). We thank the University of Missouri dairy farm staff for all their assistance, especially John Denbigh. We also thank Kaitlyn Blagg, University of Missouri Veterinary Health Center, for technical assistance. The authors have not stated any conflicts of interest.

\section{REFERENCES}

Adkins, P. R. F., S. Dufour, J. N. Spain, M. J. Calcutt, T. J. Reilly, G. C. Stewart, and J. R. Middleton. 2018. Molecular characterization of non-aureus Staphylococcus spp. from heifer intramammary infections and body sites. J. Dairy Sci. 101:5388-5403. https://doi .org/10.3168/jds.2017-13910.

Alatoom, A. A., S. A. Cunningham, S. M. Ihde, J. Mandrekar, and R. Patel. 2011. Comparison of direct colony method versus extraction method for identification of gram-positive cocci by use of Bruker Biotyper matrix-assisted laser desorption ionization-time of flight mass spectrometry. J. Clin. Microbiol. 49:2868-2873. https://doi .org/10.1128/JCM.00506-11.

Bradley, A. J., S. De Vliegher, M. J. Green, P. Larrosa, B. Payne, E. S. van de Leemput, O. Samson, D. Valckenier, T. Van Werven, H. W. Waldeck, V. White, and L. Goby. 2015. An investigation of the dynamics of intramammary infections acquired during the dry period on European dairy farms. J. Dairy Sci. 98:6029-6047. https: //doi.org/10.3168/jds.2014-8749.

Braem, G., S. De Vliegher, B. Verbist, M. Heyndrickx, F. Leroy, and L. De Vuyst. 2012. Culture-independent exploration of the teat apex microbiota of dairy cows reveals a wide bacterial species diversity. Vet. Microbiol. 157:383-390. https://doi.org/10.1016/j .vetmic.2011.12.031.

Braem, G., B. Stijlemans, W. Van Haken, S. De Vliegher, L. De Vuyst, and F. Leroy. 2014. Antibacterial activities of coagulase-negative staphylococci from bovine teat apex skin and their inhibitory effect on mastitis-related pathogens. J. Appl. Microbiol. 116:10841093. https://doi.org/10.1111/jam.12447.

Cameron, M., H. W. Barkema, J. De Buck, S. De Vliegher, M. Chaffer, J. Lewis, and G. P. Keefe. 2017. Identification of bovine-associated coagulase-negative staphylococci by matrix-assisted laser desorption/ionization time-of-flight mass spectrometry using a direct transfer protocol. J. Dairy Sci. 100:2137-2147. https://doi.org/10 .3168/jds.2016-12020.

Condas, L. A. Z., J. De Buck, D. B. Nobrega, D. A. Carson, S. Naushad, S. De Vliegher, R. N. Zadoks, J. R. Middleton, S. Dufour, J. P. Kastelic, and H. W. Barkema. 2017. Prevalence of non-aureus staphylococci species causing intramammary infections in Cana- 
dian dairy herds. J. Dairy Sci. 100:5592-5612. https://doi.org/10 .3168/jds.2016-12478.

Daly, M., E. Power, J. Björkroth, P. Sheehan, A. O'Connell, M. Colgan, H. Korkeala, and S. Fanning. 1999. Molecular analysis of Pseudomonas aeruginosa: Epidemiological investigation of mastitis outbreaks in Irish dairy herds. Appl. Environ. Microbiol. 65:27232729. https://doi.org/10.1128/AEM.65.6.2723-2729.1999.

De Visscher, A., S. Piepers, F. Haesebrouck, and S. De Vliegher. 2016. Teat apex colonization with coagulase-negative Staphylococcus species before parturition: Distribution and species-specific risk factors. J. Dairy Sci. 99:1427-1439. https://doi.org/10.3168/jds .2015-10326.

De Vliegher, S., G. Opsomer, A. Vanrolleghem, L. A. Devriese, O. C. Sampimon, J. Sol, H. W. Barkema, F. Haesebrouck, and A. de Kruif. 2004. In vitro growth inhibition of major mastitis pathogens by Staphylococcus chromogenes originating from teat apices of dairy heifers. Vet. Microbiol. 101:215-221. https://doi.org/10 .1016/j.vetmic.2004.03.020.

Derakhshani, H., K. B. Fehr, S. Sepehri, D. Francoz, J. De Buck, H. W. Barkema, J. C. Plaizier, and E. Khafipour. 2018. Invited review: Microbiota of the bovine udder: Contributing factors and potential implications for udder health and mastitis susceptibility. J. Dairy Sci. 101:10605-10625. https://doi.org/10.3168/jds.2018 -14860 .

Dohoo, I. R., J. Smith, S. Andersen, D. F. Kelton, S. Godden, and Mastitis Research Workers' Conference. 2011. Diagnosing intramammary infections: evaluation of definitions based on a single milk sample. J. Dairy Sci. 94:250-261. https://doi.org/10.3168/ jds.2010-3559.

Erskine, R. J., J. G. Unflat, R. J. Eberhart, L. J. Hutchinson, C. R. Hicks, and S. B. Spencer. 1987. Pseudomonas mastitis: Difficulties in detection and elimination from contaminated wash-water systems. J. Am. Vet. Med. Assoc. 191:811-815.

Fox, L. K. 1997. Effectiveness of laundering udder cloth towels to reduce mastitis pathogens. J. Dairy Sci. 80(Suppl. 1):234.

Fry, P. R., J. R. Middleton, S. Dufour, J. Perry, D. Scholl, and I. Dohoo. 2014. Association of coagulase-negative staphylococcal species, mammary quarter milk somatic cell count, and persistence of intramammary infection in dairy cattle. J. Dairy Sci. 97:48764885. https://doi.org/10.3168/jds.2013-7657.

Godden, S. M., J. T. Jansen, K. E. Leslie, N. L. Smart, and D. F. Kelton. 2002. The effect of sampling time and sample handling on the detection of Staphylococcus aureus in milk from quarters with subclinical mastitis. Can. Vet. J. 43:38-42.

Godden, S. M., E. Royster, W. Knauer, J. Sorg, M. Lopez-Benavides, Y. Schukken, S. Leibowitz, and E. A. French. 2016. Randomized noninferiority study evaluating the efficacy of a postmilking teat disinfectant for the prevention of naturally occurring intramammary infections. J. Dairy Sci. 99:3675-3687. https://doi.org/10 $.3168 /$ jds.2015-10379.

Gohary, K., and S. McDougall. 2018. Predicting intramammary infection status at drying off using indirect testing of milk samples. N. Z. Vet. J. 66:312-318. https://doi.org/10.1080/00480169.2018 .1509741.

Hiitiö, H., H. Simojoki, P. Kalmus, J. Holopainen, S. Pyörälä, and S. Taponen. 2016. The effect of sampling technique on PCRbased bacteriological results of bovine milk samples. J. Dairy Sci. 99:6532-6541. https://doi.org/10.3168/jds.2015-10811.

Kirk, J. H., and P. C. Bartlett. 1984. Nonclinical Pseudomonas aeruginosa mastitis in a dairy herd. J. Am. Vet. Med. Assoc. 184:671673.

Mahmmod, Y. S., I. C. Klaas, S. S. Nielsen, J. Katholm, and N. Toft. 2013. Effect of presampling procedures on real-time PCR used for diagnosis of intramammary infections with Staphylococcus aureus in dairy cows at routine milk recordings. J. Dairy Sci. 96:22262233. https://doi.org/10.3168/jds.2012-6059.

Middleton, J. R., L. K. Fox, G. Pighetti, and C. Petersson-Wolfe. 2017. Laboratory Handbook on Bovine Mastitis. National Mastitis Council, New Prague, MN.

Naqvi, S. A., J. De Buck, S. Dufour, and H. W. Barkema. 2018. Udder health in Canadian dairy heifers during early lactation. J. Dairy Sci. 101:3233-3247. https://doi.org/10.3168/jds.2017-13579.

Nonnemann, B., U. Lyhs, L. Svennesen, K. A. Kristensen, I. C. Klaas, and K. Pedersen. 2019. Bovine mastitis bacteria resolved by MALDI-TOF mass spectrometry. J. Dairy Sci. 102:2515-2524. https:// doi.org/10.3168/jds.2018-15424.

Piessens, V., E. Van Coillie, B. Verbist, K. Supré, G. Braem, A. Van Nuffel, L. De Vuyst, M. Heyndrickx, and S. De Vliegher. 2011. Distribution of coagulase-negative Staphylococcus species from milk and environment of dairy cows differs between herds. J. Dairy Sci. 94:2933-2944. https://doi.org/10.3168/jds.2010-3956.

Pitkälä, A., M. Haveri, S. Pyörälä, V. Myllys, and T. HonkanenBuzalski. 2004. Bovine mastitis in Finland 2001: Prevalence, distribution of bacteria, and antimicrobial resistance. J. Dairy Sci 87:2433-2441. https://doi.org/10.3168/jds.S0022-0302(04)73366 $-4$

Popović, N. T., S. P. Kazazić, I. Strunjak-Perović, and R. ČožRakovac. 2017. Differentiation of environmental aquatic bacterial isolates by MALDI-TOF MS. Environ. Res. 152:7-16. https://doi .org/10.1016/j.envres.2016.09.020.

Rainard, P., G. Foucras, J. R. Fitzgerald, J. L. Watts, G. Koop, and J. R. Middleton. 2018. Knowledge gaps and research priorities in Staphylococcus aureus mastitis control. Transbound. Emerg. Dis. 65:149-165. https://doi.org/10.1111/tbed.12698.

Roberson, J. R., L. K. Fox, D. D. Hancock, J. M. Gay, and T. E. Besser. 1994. Ecology of Staphylococcus aureus isolated from various sites on dairy farms. J. Dairy Sci. 77:3354-3364. https://doi .org/10.3168/jds.S0022-0302(94)77277-5.

Rowbotham, R. F., and P. L. Ruegg. 2016. Associations of selected bedding types with incidence rates of subclinical and clinical mastitis in primiparous Holstein dairy cows. J. Dairy Sci. 99:47074717. https://doi.org/10.3168/jds.2015-10675.

Schukken, Y. H., J. A. H. Smit, F. J. Grommers, D. Vandegeer, and A. Brand. 1989. Effect of freezing on bacteriologic culturing of mastitis milk samples. J. Dairy Sci. 72:1900-1906. https://doi.org/ 10.3168/jds.S0022-0302(89)79309-7.

Sol, J., H. W. Barkema, I. M. Berghege, G. H. Borst, L. J. Hoornick, and O. C. Sampimon. 1998. Mastitis following drying up associated with teat wipes contaminated with Pseudomonas aeruginosa. Tijdschr. Diergeneeskd. 123:112-113.

Tenhagen, B. A., G. Koster, J. Wallmann, and W. Heuwieser. 2006. Prevalence of mastitis pathogens and their resistance against antimicrobial agents in dairy cows in Brandenburg, Germany. J. Dairy Sci. 89:2542-2551. https://doi.org/10.3168/jds.S0022 $-0302(06) 72330-\mathrm{X}$.

Villanueva, M. R., J. W. Tyler, and M. C. Thurmond. 1991. Recovery of Streptococcus agalactiae and Staphylococcus aureus from fresh and frozen bovine milk. J. Am. Vet. Med. Assoc. 198:1398-1400.

Woodward, W. D., T. E. Besser, A. C. Ward, and L. B. Corbeil. 1987. In vitro growth inhibition of mastitis pathogens by bovine teat skin normal flora. Can. J. Vet. Res. 51:27-31.

\section{ORCIDS}

J. R. Middleton @ https://orcid.org/0000-0003-0791-6604

P. R. F. Adkins ๑ https://orcid.org/0000-0003-3363-5961 